\title{
$\mathrm{ADHD}$ 아동 어머니의 삶의 질 구조모형
}

박찬경 ${ }^{1}$, 전미양 2

'진주보건대학교 간호학과, ${ }^{2 ㄱ ㅕ ㅇ ㅅ ㅏ ㅇ ㄷ ㅐ ㅎ ㅏ ㄱ ㄱ ㅛ ~ ㄱ ㅏ ㄴ ㅎ ㅗ ㄷ ㅐ ㅎ ㅏ ㄱ ~ ㄱ ㅏ ㄴ ㅎ ㅗ ㅎ ㅏ ㄱ ㄱ ㅘ ~ · ~ ㄱ ㅓ ㄴ ㄱ ㅏ ㅇ ㄱ ㅘ ㅎ ㅏ ㄱ ㅇ ㅕ ㄴ ㄱ ㅜ ㅇ ㅝ ㄴ ~}$

\section{A Structural Equation Model on Quality of Life of Mothers of Children with Attention Deficit Hyperactivity Disorder}

\author{
Chan Gyeong Park ${ }^{1}$, Mi Yang Jeon ${ }^{2}$ \\ ${ }^{1}$ Department of Nursing, Jinju Health College, Jinju; ${ }^{2}$ College of Nursing $\cdot$ Institute of Health Science, Gyeongsang National University, Jinju, Korea
}

Purpose: The aim of this study was to explore how characteristics of ADHD children affect social support for mothers, parenting stress, parenting sense of competence, coping, and quality of life. The conceptual model was based on the Lazarus and Folkman's stress-evaluation-coping theory. Methods: Data were collected 208 mothers of children with ADHD. Data were analysed using SPSS 18.0 and AMOS 18.0 programs. Results: The proposed model was good fit for the data based on the model fit indices. Parenting stress, parenting sense of competence and coping directly affected quality of life but characteristics of the children and social support had only an indirect effect. The explanatory power of these variables was $52.1 \%$. Conclusion: The results of this study indicate that nursing strategies to increase social support for mothers with ADHD children, lowers parenting stress, improves parenting sense of competence, and guides the parents to choose appropriate coping. In particular, as social support has the strongest influence on the quality of life, it is necessary to develop nursing intervention programs that utilize social support for parents with ADHD children.

Key words: ADHD (Attention deficit hyperactivity disorder), Parenting, Mother, Quality of life

\section{서 론}

\section{연구의 필요성}

주의력결핍과잉행동장애(Attention Deficit Hyperactivity Disorder, $\mathrm{ADHD})$ 는 학령전기 및 학령기 아동에서 가장 빈번하게 발생하는 정 신과적 질환이다[1]. 서울시 광역정신보건센터(2005)는 초등학생의

Corresponding author Mi Yang Jeon College of Nursing - Institute of Health Science, Gyeongsang National University, 816-15 Jinju-daero, Jinju 52727, Korea TEL +82-55-772-8261 FAX+82-55-772-8222 E-MAIL myjeon68Agnu.ac.kr *이 논문은 제 1 저자의 박사학위논문의 일부를 발췌한 것임.

*This manuscript is based on a part of the first author's dissertation from Gyeongsang National University.

Key words 주의력결핍과잉행동장애, 양육, 어머니, 삶의 질

Received 8 April 2017 Received in revised form 15 May 2017

Accepted 25 May 2017

(a) This is an Open Access article distributed under the terms of the Creative Commons Attribution NonCommercial License (http://creativecommons.org/licenses/by-nc/4.0/] which permits unrestricted noncommercial use, distribution, and reproduction in any medium, provided the original work is properly cited.
$\mathrm{ADHD}$ 유병률을 $14.8 \%$ 로 보고하였으며[2], 건강보험심사평가원은 최 근 5년간(2007 2011년) 20세 이하의 소아. 청소년을 대상으로 ADHD 와 관련된 진료 내용을 분석한 결과, 진료인원이 연평균 $4.4 \%$ 증가한 것으로 보고하였다[3].

$\mathrm{ADHD}$ 아동은 쉽게 흥분하고 좌절하고 감정의 기복이 심하고, 외 부자극에 대해 산만하게 반응하는 특성을 가지고 있다[4]. 또한 $\mathrm{ADHD}$ 아동은 이와 같은 문제 행동을 반복하기 때문에 부모-자녀문 제, 형제간의 문제와 부부갈등 등 가족구성원 전체에게 광범위한 영 향을 미친다[5]. 특히 $\mathrm{ADHD}$ 아동의 어머니는 일차적인 양육 책임자로 서, 아동의 예측불허적인 행동 때문에 극도의 긴장감과 스트레스를 경 험하게 되며, 정상자녀의 어머니보다 양육 스트레스가 높고, 양육효능 감은 낮으며 부정적인 양육행동을 더 많이 하는 것으로 보고되고 있 다[6,7]

또한 $\mathrm{ADHD}$ 아동 어머니는 질병에 대한 사회적 인식부족으로 인해 $\mathrm{ADHD}$ 아동을 양육하는 것을 멍에를 안고 헤쳐나가는 것으로 표현하 
였다. 특히 $\mathrm{ADHD}$ 아동들이 정신과 치료를 받는 것 때문에 사회적으 로 낙인 받을 것에 대한 두려움이 있었다. 그리고 현실에서 엄마의 몫 을 내려놓고 싶지만 여전히 놓을 수 없는 끈을 잡고 있다고 호소하였으 며 이로 인해 높은 수준의 양육 스트레스와 정서적 고통과 부적응을 경험하며 삶의 질이 낮은 것으로 보고하였다[8]. $\mathrm{ADHD}$ 아동 어머니들 은 심리적 적응과정에서 분노, 아무것도 가치 있는 것이 없다고 느끼고 정상아동에 대한 환상을 상실함으로 인해 우울과 좌절을 경험하며, 이를 통해 삶의 의미가 재조정되고 결혼관계에서 역할 분담의 어려움, 사회적 관계에서의 어려움이나 사회적 접촉 회피 등을 보였다[9]. 이는 어머니들이 $\mathrm{ADHD}$ 아동을 양육하는데 장애요인으로 작용하여 부모 는 자녀에게 부정적 상호작용을 하게 되고 이는 다시 아동의 문제행동 을 유발하는 악순환을 유발한다[7,10]. ADHD 아동의 어머니는 $\mathrm{ADHD}$ 아동의 문제 행동과 가족 갈등을 매개하는 중요한 역할을 하 므로 어머니의 스트레스 관리와 삶의 질은 $\mathrm{ADHD}$ 아동을 양육하는 데 매우 중요한 요인이다[11]. 그러므로 $\mathrm{ADHD}$ 아동 어머니의 삶의 질 과 관련된 요인을 규명하고 이를 근거로 $\mathrm{ADHD}$ 아동 어머니의 삶의 질을 증진시킬 수 있는 간호전략을 개발하고 적용하는 것이 필요하다. 그러나 국내에는 $\mathrm{ADHD}$ 아동 어머니의 삶의 질에 영향을 미치는 요인 을 탐색한 연구[6]는 보고되었으나 이론을 토대로 삶의 질을 포괄적으 로 설명할 수 있는 모형을 구축하여 변인들간의 경로를 설명한 연구는 거의 없는 실정이다.

이에 본 연구에서는 $\mathrm{ADHD}$ 아동 어머니의 삶의 질을 설명하기 위해 Lazarus와 Folkman[12]의 스트레스-평가-대처 이론과 Cohen과 Wills[13]의 사회적 지지를 근거로 모형을 구축하고자 한다. Lazarus와 Folkman[12]의 스트레스-평가-대처 이론에서 스트레스는 '개인이 가진 자원을 청구하거나 자신의 요구가 자신이 지닌 자원의 한계를 초과하 여 개인의 안녕을 위협한다라고 평가되는 인간과 환경간의 관계이며, 인지평가가 대처자원과 함께 매개과정에서 중요한 역할을 하고 있음 을 설명하는 대표적인 이론이다. 이 이론에 의하면, $\mathrm{ADHD}$ 아동 어머 니가 양육 상황과 관련된 스트레스원을 어떻게 인지하고 양육효능감 을 얼마나 가지고 있으며, 어떻게 대처하느냐에 따라 삶의 질이 달라질 수 있다[6,7,14,15]. 그러므로 $\mathrm{ADHD}$ 아동 어머니가 아동을 돌보면서 지 치지 않고 자신의 삶에 적응해가도록 돕기 위해 아동의 양육과정에서 발생하는 스트레스에 대한 인지평가와 대처자원간의 관계를 파악하 여 중재에 활용한다면 양육 상황에 대한 스트레스를 감소시켜 삶의 질 향상을 기대 할수 있을 것이다.

따라서, 본 연구에서는 선행 연구 결과를 근거로 $\mathrm{ADHD}$ 아동을 양 육하는 어머니의 삶의 질 관련 변인들 중에서 Lazarus과 Folkman[12] 의 스트레스-평가-대처 이론에서 인지 평가로 제시한 양육 스트레스 와 양육효능감, Cohen과 Wills[13]의 사회적 지지를 매개변수로 대처전 략, 스트레스의 적응 결과로서 삶의 질에 미치는 영향을 파악하여, 삶
의 질과 관련된 모형을 구축하고 검증하고자 한다.

\section{연구 목적}

본 연구의 목적은 $\mathrm{ADHD}$ 아동 어머니의 삶의 질을 증진시키는 간호 중재를 개발하는데 근거자료로 활용할 수 있는 $\mathrm{ADHD}$ 아동 어머니의 삶의 질 구조모형을 구축하고 모형의 적합도를 검증하기 위함이며 구 체적 목적은 다음과같다.

첫째, 선행 연구의 고찰을 통해 $\mathrm{ADHD}$ 아동 어머니의 삶의 질에 영 향을 미치는 것으로 확인된 개념을 이론적으로 구성하여 $\mathrm{ADHD}$ 아 동 어머니의 삶의 질 모형을 제시한다.

둘째, 제시된 가설모형과 실제 자료간의 적합도를 검증하고 관련 변 인들간의 관계를 보다 잘 설명하는 수정모형을 제시한다.

셋째, $\mathrm{ADHD}$ 아동 어머니의 삶의 질에 영향을 미치는 요인들의 직. 간접 효과를 파악한다.

\section{가설적 모형}

본 연구의 가설적 모형은 외생변수 2 개와 내생변수 4 개로 구성하였 다. 본 연구의 외생변수는 아동 특성, 사회적 지지이며, 내생변수는 양 육 스트레스와 양육효능감, 대처 및 삶의 질로 구성하였다(Figure 1).

\section{연구 가설}

가설적 모형의 각 경로에서 도출된 가설은 다음과 같다.

\section{양육 스트레스를 내생변수로 하는 가설}

가설 1. 자녀의 특성은 양육 스트레스에 양 $(+)$ 의 영향을 미칠 것이 다 $\left(\gamma_{11}\right)$.

가설 2. 사회적 지지는 양육 스트레스에 음(-)의 영향을 미칠 것이다 $\left(\gamma_{12}\right)$.

\section{양육효능감을 내생변수로 하는 가설}

가설 3. 자녀의 특성은 양육효능감에 음(-)의 영향을 미칠 것이다 $\left(\gamma_{21}\right)$. 가설 4. 사회적 지지는 양육효능감에 양 $(+)$ 의 영향을 미칠 것이다 $\left(\gamma_{22}\right)$ 가설 5. 양육 스트레스와 양육효능감은 서로 영향을 미칠 것이다 $\left(\beta_{21}, \beta_{12}\right)$.

\section{대처를 내생변수로 하는 가설}

가설 6. 사회적 지지는 대처에 양 $(+)$ 의 영향을 미칠 것이다 $\left(\gamma_{32}\right)$. 가설 7. 양육 스트레스는 대처에 음(-)의 영향을 미칠 것이다 $\left(\beta_{31}\right)$. 가설 8 . 양육효능감은 대처에 양 $(+)$ 의 영향을 미칠 것이다 $\left(\beta_{32}\right)$. 


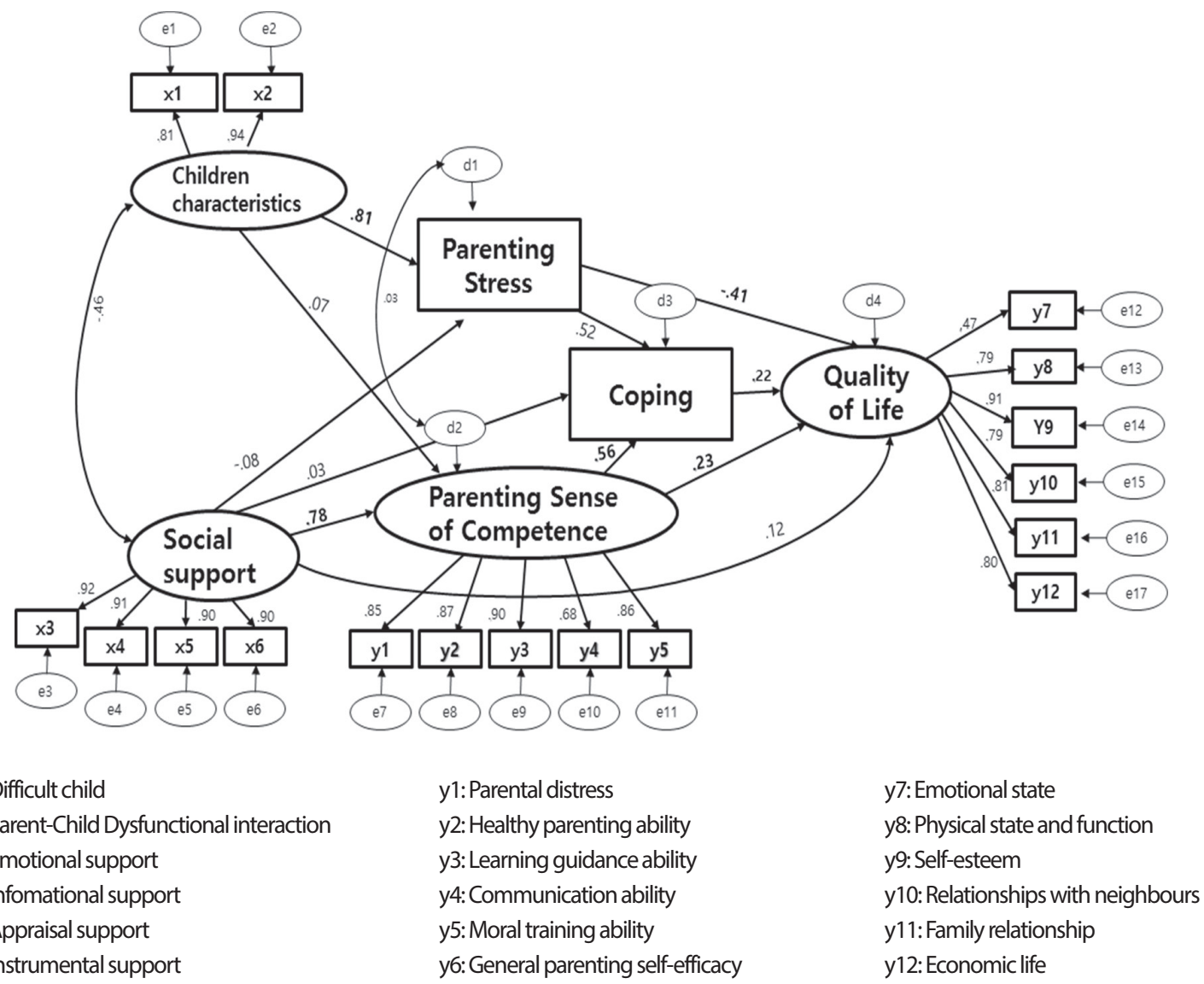

Figure 1. Path diagram of hypothetical model.

\section{삶의 질을 내생변수로 하는 가설}

가설 9. 사회적 지지는 삶의 질에 양 $(+)$ 의 영향을 미칠 것이다 $\left(\gamma_{42}\right)$. 가설 10. 양육스트레스는 삶의 질에 음(-)의 영향을 미칠 것이다 $\left(\beta_{41}\right)$. 가설 11. 양육효능감은 삶의 질에 양 $(+)$ 의 영향을 미칠 것이다 $\left(\beta_{42}\right)$. 가설 12 . 대처는 삶의 질에 양 $(+)$ 의 영향을 미칠 것이다 $\left(\beta_{43}\right)$.

\section{연구 방법}

\section{연구 설계}

본 연구는 Cohen과 Wills[13]의 사회적 지지 개념을 매개변수로 하여 Lazarus와 Folkman[11]의 스트레스-평가-대처 이론을 확장한 이론을 기반으로, 선행 연구와 문헌고찰을 통해 $\mathrm{ADHD}$ 아동 어머니의 삶의 질을 설명하는 변인들간의 인과관계에 대한 가설적 모형을 제시하고 수집된 자료를 통해 모형의 적합도와 연구 가설을 검정하는 구조모형 검증 연구이다.

\section{연구 대상}

본 연구의 대상자는 전국에 거주하는 ADHD 아동 어머니를 임의 선정하여 참여에 동의하는 자를 편의 표출하였다. 연구 참여자의 구체 적인 선정기준은 1) 전문의로부터 $\mathrm{ADHD}$ 진단을 받은 아동을 양육하 는 어머니, 2) 의사소통이 가능한 자, 3) 연구의 목적을 이해하고 연구 참여에 자발적으로 동의한 자이다.

본 연구에서 대상자의 수는 구조방정식 모형에서 표본의 크기를 선 정하는 방법 중 최대우도법을 기준으로 하였으며, 자료가 다변량 정규 성을 충족하였기 때문에 탈락률을 고려해 250명을 표집대상으로 하 였고, 부적절한 응답 42 부를 제외한 208 부의 자료를 분석하였으므로 표본수는 충족되었다.

\section{연구 도구}

본 연구에서 각 도구의 문항 중 확인적 요인분석에서 분산추출지수 가. 50 이하인 문항은 제거한 후 분석하였다. 도구의 최종 문항은 연구 대상자의 자녀 특성 24 개 문항, 사회적 지지 25 개 문항, 양육 스트레스 
12 개 문항, 양육효능감 37 개 문항, 스트레스 대처 방식 44 개 문항, 삶의 질 47 개 문항 등 총 189 개 문항으로 구성되었다.

\section{아동의 특성}

아동의 특성은 Abidin[16]이 개발하고 Kim과 Do[17]가 수정 - 보완한 Parenting Stress Index/Short Form (PSI/SF) 도구로 측정하였다. 이 도구 는 2 개 하위 영역(자녀의 까다로운 기질, 부모-자녀간의 역기능적인 상 호작용), 24 개 문항, 5점 Likert 척도이며 점수가 높을수록 그 특성이 높 음을 의미한다. Kim과 Do[17]의 연구에서 Cronbach's a는 자녀의 까다 로운 기질은 .88 , 부모-자녀간 역기능적 상호작용은 .86 이었다. 본 연구 에서 3 개 문항이 제거되어 총 21 개 문항-(까다로운 기질 11 문항, 부모자간 역기능적 상호작용 10 문항)이 사용되었으며, Cronbach's $\alpha$ 는 자녀 의 까다로운 기질은 90 부모-자녀간 역기능적 상호작용은 .93 이며 전 체는 .95 였다.

\section{사회적 지지}

어머니 개인이 지각한 가족의 사회적 지지는 Park[18]이 개발한 사회 적 지지 척도를 사용하여 측정하였다. 이 도구는 4 개 하위 영역(정서 적, 정보적, 평가적, 물질적 지지), 25개 문항, 5점 Likert 척도이며, 점수 가 높으면 사회적 지지가 높은 것을 의미한다. 도구가 개발 당시 Cronbach's $\alpha$ 는 .95였다[17]. 본 연구에서 제거되는 문항이 없었으며 Cronbach's $\alpha$ 는 정서적 지지 .88 , 정보적 지지 .89 , 평가적 지지 .85 물질적 지 지 .87 이며 전체는 .96 이었다.

\section{양육 스트레스}

어머니의 양육 스트레스는 Abidin[16]이 개발하고 Kim과 Do[17]가 번안한 Parenting Stress Index/Short Form (PSI/SF) 도구 36개 문항 중 부 모의 고통(Parental Distress) 12개 문항, 5점 Likert 척도로 측정하였으 며, 점수가 높으면 양육 스트레스가 높은 것을 의미한다. Kim과 Do[17] 의 연구에서 Cronbach's $\alpha$ 는 .81이었고, 본 연구에서 6 개 문항이 제거되 어 총 6 개 문항이 사용되었으며, Cronbach's $\alpha$ 는 .86이었다.

\section{양육효능감}

어머니의 양육효능감은 Choi와 Chung[19]이 개발한 도구를 사용하 여 측정하였다. 이 도구는 5 개 영역(양육효능감 11 개 문항, 건강하게 양 육하는 능력 7개 문항, 의사소통능력 9개 문항, 학습지도능력 6개 문항, 훈육능력 4개 문항) 37 개 문항으로 구성된 5점 Likert 척도로 점수가 높을수록 양육효능감이 높다는 것을 의미한다. Choi와 Chung[19]의 연구에서 도구의 신뢰도 Cronbach's $\alpha$ 는 .92이며 본 연구에서 4 개 문항 이 제거되어 총 33 개 문항(양육효능감 10 개 문항, 건강하게 양육하는 능력 7개 문항, 의사소통 능력 7개 문항, 학습지도 능력 6개 문항, 훈육
능력 3개 문항)이 사용되었으며 영역별 Cronbach's a는 전반적인 양육 효능감 .85 , 건강하게 양육하는 능력 . 74 , 의사소통 능력 .86 , 학습지도 능력. 82 , 훈육 능력.65이며 전체는 .95 였다.

\section{스트레스 대처}

스트레스 대처는 Lazarus와 Folkman[12]이 개발한 68개 문항의 스 트레스 대처방식 척도를, Yoon[20]이 문제중심적 대처와 정서중심적 대처로 수정한 도구를 이용하였다. 이 도구에서 문제중심적 대처는 개인-환경 관련 문제를 변화시키려고 하는 노력을 의미하는 21 개 문 항, 정서중심적 대처는 스트레스로 유발되는 감정을 통제하려는 노력 을 의미하는 23 개 문항, 4 점 Likert 척도로 측정하였으며 점수가 높을 수록 각 대처 방식의 이용정도가 높음을 의미한다. Yoon[20]의 연구에 서 Cronbach's $\alpha$ 는 문제중심적 대처. 86 , 정서중심적 대처 .76, 전체는 .87 이었다. 본 연구에서 29 개 문항이 제거되어 총 15 개 문항(문제중심 적 대처 10 개 문항, 정서중심적 대처 5 개 문항)이 사용되었으며 Cronbach's $\alpha$ 는 문제중심적 대처 . 83 , 정서중심적 대처. 73 이며 전체는 .83 이 었다.

\section{삶의 질}

$\mathrm{ADHD}$ 아동 어머니의 삶의 질은 $\mathrm{No}[21]$ 가 개발한 삶의 질 측정도구 를 이용하여 측정하였다. 이 도구는 6개 하위영역(정서상태 9개 문항, 경제생활 11 개 문항, 자아존중감 8 개 문항, 신체상태와 기능 9개 문항, 이웃관계 4개 문항, 가족관계 6개 문항) 47문항 4점 Likert 척도로 점수 가 높을수록 삶의 질이 높음을 의미한다. 도구 개발당시 Cronbach's a 는 .94였다. 그러나 본 연구에서 11 개 문항을 제거하여 36 개 문항(정서 상태 7 개 문항, 경제생활 10 개 문항, 자아존중감 8 개 문항, 신체상태와 기능 4 개 문항, 이웃관계 3 개 문항, 가족관계 4 개 문항)으로 측정하였 으며 본 연구에서 도구의 신뢰도 Cronbach's $\alpha$ 는 정서상태 .87, 경제생 활 .87 , 자아존중감 .87 , 신체상태와 기능 .74 , 이웃관계 .65 , 가족관계 .62 이며 전체는 .94 였다.

\section{자료 수집 방법}

$\mathrm{G}$ 대학교의 연구 윤리심의위원회(IRB)의 승인(GIRB-A14-X-0041)을 거쳐 2014년 10월 1일부터 2015년 4월 10일까지 서울, 부산, 경남 지역의 $\mathrm{ADHD}$ 아동 보호자 모임, 정신치료기관과 지역사회 정신보건센터 및 사회재활시설에서 자료를 수집하였다. 또한 정신건강의학과에서 $\mathrm{ADHD}$ 진단을 받고 외래를 방문하여 상담을 받는 아동의 어머니를 대상으로 자료를 수집하기 위해 G대학교병원의 IRB의 승인 (GNUH2014-12-010)을 받았으며 2015년 1월 10일부터 2015년 4월 10일 까지 자료를 수집하였다. 자료 수집은 연구자가 해당 대상자에게 연구 의 목적과 방법을 설명하고 구조화된 설문지를 배부하고 연구 대상자 
가 직접 설문지를 작성하도록 하였다.

\section{자료 분석 방법}

수집된 자료는 IBM SPSS Statistics 18.0과 Amos 18.0을 이용하여 일 반적 특성 및 연구변수는 서술통계로, 연구 도구의 신뢰도 점증은 Cronbach's $\alpha$ 로, 연구변수의 상관관계 및 다중공선성은 Pearson correlation coefficient로 검증하였으며, 표본의 정규성은 일변량 정규성 검 증을 통하여 평균, 표준편차, 왜도, 첨도로 확인하였고 구조모형 분석 을 위한 타당도를 확인하기 위하여 확인적 요인분석(Confirmatory Factor Analysis, $\mathrm{CFA}$ )을 실시하였다. 구조방정식 모형분석을 위해 최대 우도법을 이용하였으며, 모형의 적합도 평가는 절대적합지수인 $\chi^{2}, \chi^{2} /$ $d f$, 잔차평균자승 이중근(Root Mean-Square Residual, RMR), 근사오차 평균자승의 이중근(Root Mean Squared Error of Approximation, RM$\mathrm{SEA}$ ), 적합지수(Goodness of Fit Index, GFI), 조정적합지수(Adjusted Goodness of Fit Index, AGFI)를 구하였다. 증분적합지수로는 표준화적 합지수(Normed Fit Index, NFI), (Tucker-Lewis Index, TLI), 비교적합지 수(Comparative Fit Index, CFI)를 이용하였다.

\section{윤리적 고려}

G대학교(GIRB-A14-X-0041)와 G대학교병원(GNUH2014-12-010) 연 구 윤리심의위원회의 승인을 받은 후 자료를 수집하였다. 설문에 소요 되는 시간은 30 45분 정도이며, 설문이 끝난 후에는 감사의 표시로 소 정의 선물을 제공하였다. 연구 참여자에게 연구 목적과 방법, 이익과 잠재적 위험, 연구가 초래할 수 있는 불편 등에 대해 설명한 후 참여 동 의서에 자발적으로 서면동의한 대상자에게 설문에 참여하도록 하였 다. 설문지는 작성 즉시 회수하였다.

\section{연구 결과}

\section{대상자와 자녀의 일반적 특성 대상자의 일반적 특성}

본 연구 대상자의 연령분포는 40 44세 $40.4 \%, 40$ 세 미만 $30.8 \%, 45$ 세 이상 $28.8 \%$ 순이었고, 평균 연령은 42.04 세이었다. 결혼상태는 기혼이 $93.8 \%$ 이고, 학력은 고졸 이하 $53.8 \%$, 대졸 이상 $46.2 \%$ 였으며, 가구의 월 소득은 350 만원 이상 $54.8 \%$ 로 가장 많았고, 직업이 있는 대상자는 $86.5 \%$ 였다.(Table 1).

\section{대상자의 자녀의 일반적 특성}

$\mathrm{ADHD}$ 아동이 1 명인 경우가 $97.6 \%$ 였으며 아동의 성별은 남자 $81.3 \%$, 여자 $18.7 \%$ 였다. 학년은 초등학교 저학년 $42.4 \%$, 고학년 $26.5 \%$, 중학교 이상 $31.2 \%$ 였다. 자녀의 수는 평균 1.9 명이고 2 명이 $67.8 \%$ 로 가장 많았
으며, 출생순위는 첫째 $49.0 \%$, 둘째 $47.6 \%$, 셋째 $3.4 \%$ 순이었다. ADHD 와 동반된 문제는 학습장애 $49.5 \%$, 불안 $37.5 \%$, 인터넷 중독 $21.6 \%$, 틱장 애 $18.3 \%$ 순으로 많았다. ADHD 진단기간은 2년 미만이 $50.5 \%$ 이며 평 균 2.7년이었다. 약물치료를 받은 경험은 $36.1 \%$ 였으며 약물치료 경험이 있는 아동의 약물치료 받은 기간은 평균 2.3년이었다. ADHD 아동 양 육 관련 부모교육 경험은 있다가 $37.5 \%$ 였다(Table 1).

\section{연구변수의 서술적 통계와 정규성 검증}

연구 대상자의 자녀 특성은 $3.13 \pm 0.69$ 점이었으며, 사회적 지지는 $3.52 \pm 0.60$ 점이었고, 양육 스트레스는 $3.10 \pm 0.78$ 점이었으며, 양육효능 감은 $3.40 \pm 0.47$ 점이었다. 대처는 $2.54 \pm 0.59$ 점이며, 삶의 질은 $3.06 \pm 0.47$ 점이었다. 표본의 정규성을 검증한 결과, 본 연구에서 사용된 변수들 의 왜도(0.02 0.62)와 첨도(0.04 1.77)가 정규성 검정 기준에 부합하여 정규분포하였다(Table 2).

\section{연구변수의 상관관계와 다중공선성 분석}

본 연구에 이용된 변수간의 상관관계를 살펴보면, 삶의 질은 사회적 지지 $(\mathrm{r}=.48, p<.001)$ 와, 양육효능감 $(\mathrm{r}=.46, p<.001)$ 과, 문제중심적 대처 $(\mathrm{r}=.39, p<.001)$ 와 양의 상관관계이고, 자녀특성 $(\mathrm{r}=-.42, p<.001$ 과 $)$, 양 육 스트레스 $(\mathrm{r}=-.48, p<.001)$ 와 음의 상관관계를 나타내었다. 정서중심 적 대처는 문제중심적 대처 $(\mathrm{r}=.31, p<.001)$ 와 양의 상관관계이고, 문제 중심적 대처는 사회적 지지 $(\mathrm{r}=.38, p<.001)$ 와, 양육효능감 $(\mathrm{r}=.49$, $p<.001)$ 과 양의 상관관계를 나타내었다. 양육효능감은 사회적 지지 $(\mathrm{r}=.69, p<.001)$ 와 양의 상관관계를 나타내었고 자녀특성 $(\mathrm{r}=-.26$, $p<.001)$ 과, 양육 스트레스 $(\mathrm{r}=-.28, p<.001)$ 는 음의 상관관계를 나타내 었다. 양육 스트레스는 자녀 특성 $(\mathrm{r}=.78, p<.001)$ 과 양의 상관관계이고, 사회적 지지 $(\mathrm{r}=-.44, p<.001)$ 와 음의 상관관계를 나타내었다. 연구변수 들 간의 상관계수 절대값이 .03 .78로 나타나 변수들간의 다중공선성 은 없는 것으로 판단되었다.

\section{측정변수에 대한 확인적 요인분석}

본 연구에서 확인적 요인분석을 실시하여, 표준화 요인적재치(standardized factor loading)가 0.309로 0.5 보다 작게 나타난 정서중심적 대 처를 제거하였으며, 자녀특성, 사회적 지지, 양육 스트레스, 양육효능 감, 문제중심적 대처, 삶의 질의 표준화 요인적재치는 0.5 이상으로 해 당변수를 잘 설명하고 있는 것으로 나타나 모형분석에 포함되었다. 본 연구에서 척도의 신뢰도와 타당도를 평가하기 위해 개념신뢰도와 분 산추출지수(Average Variance Extracted, AVE)를 확인한 결과, 수용기준 을 만족하였으며, 분산추출지수가 상관계수의 잠재변수간의 제곱보 다 모두 큰 것으로 나타나 판별타당도를 확보하였다(Table 3). 
Table 1. General Characteristics of Participants

\begin{tabular}{|c|c|c|c|c|}
\hline Variables & Characteristics & Categories & n (\%) & $M \pm S D$ \\
\hline \multirow[t]{13}{*}{ Mother } & \multirow[t]{3}{*}{ Age (year) } & $<40$ & $64(30.8)$ & \multirow[t]{11}{*}{$42.04 \pm 4.59$} \\
\hline & & $40 \sim 44$ & $84(40.4)$ & \\
\hline & & $\geq 45$ & $60(28.8)$ & \\
\hline & \multirow[t]{2}{*}{ Marital status } & Married & $195(93.8)$ & \\
\hline & & Others & $13(6.2)$ & \\
\hline & \multirow[t]{2}{*}{ Educational level } & $\leq$ High school & $112(53.8)$ & \\
\hline & & $\geq$ College & $96(46.2)$ & \\
\hline & \multirow{2}{*}{$\begin{array}{l}\text { Monthly income } \\
(10,000 \text { won })\end{array}$} & $<350$ & $94(45.2)$ & \\
\hline & & $\geq 350$ & $114(54.8)$ & \\
\hline & \multirow[t]{2}{*}{ Employed } & Yes & $180(86.5)$ & \\
\hline & & No & $28(13.5)$ & \\
\hline & \multirow{2}{*}{$\begin{array}{l}\text { Number of children } \\
\text { diagnosed with ADHD }\end{array}$} & 1 & $203(97.6)$ & \multirow[t]{2}{*}{$1.03 \pm 0.25$} \\
\hline & & $\geq 2$ & $5(2.4)$ & \\
\hline \multirow[t]{28}{*}{ Child with ADHD } & \multirow[t]{2}{*}{ Gender } & Male & $169(81.3)$ & \\
\hline & & Female & 39 (18.7) & \\
\hline & \multirow[t]{3}{*}{ Number of children } & 1 & $43(20.7)$ & \\
\hline & & 2 & $141(67.8)$ & \\
\hline & & 3 & $24(11.5)$ & \\
\hline & \multirow[t]{3}{*}{ Birth order } & First & $102(49.0)$ & \\
\hline & & Second & $99(47.6)$ & \\
\hline & & Third & $7(3.4)$ & \\
\hline & \multirow[t]{8}{*}{ Combined condition* } & Tic disorder & $38(18.3)$ & \\
\hline & & Depression & $16(7.7)$ & \\
\hline & & Anxiety & $78(37.5)$ & \\
\hline & & Oppositional defiant disorder & $35(16.8)$ & \\
\hline & & Learning disorder & $103(49.5)$ & \\
\hline & & Language disorder & $19(9.1)$ & \\
\hline & & Internet addition & $45(21.6)$ & \\
\hline & & None & $33(15.9)$ & \\
\hline & \multirow{2}{*}{$\begin{array}{l}\text { Duration after diagnosis } \\
\text { (year) }(n=103)\end{array}$} & $<2$ & $52(50.5)$ & \multirow[t]{4}{*}{$2.70 \pm 2.99$} \\
\hline & & $\geq 2$ & $51(49.5)$ & \\
\hline & \multirow[t]{2}{*}{ Medication } & Yes & $75(36.1)$ & \\
\hline & & No & $133(63.9)$ & \\
\hline & \multirow{4}{*}{$\begin{array}{l}\text { Duration of medication } \\
\text { (year) }(n=75)\end{array}$} & $<1$ & $24(23.3)$ & \multirow[t]{4}{*}{$2.34 \pm 2.73$} \\
\hline & & 1 & $28(27.2)$ & \\
\hline & & $2 \sim 4$ & $34(33.0)$ & \\
\hline & & $\geq 5$ & $17(16.5)$ & \\
\hline & \multirow[t]{2}{*}{ Current drug use $(n=75)$} & Yes & $57(76.0)$ & \\
\hline & & No & $18(24.0)$ & \\
\hline & \multirow{2}{*}{$\begin{array}{l}\text { Received } \\
\text { parenting education }\end{array}$} & Yes & $78(37.5)$ & \\
\hline & & No & $130(62.5)$ & \\
\hline
\end{tabular}

*Multiple responses.

\section{$\mathrm{ADHD}$ 아동 어머니의 삶의 질 구조모형 분석} 모형의 적합도 검정

본 연구의 가설적 모형의 적합도 검증을 실시한 결과, $\chi^{2}=289.81$ $(p<.001)$ 로 부적합한 것으로 나왔다. 그러나 $\chi^{2}$ 를 자유도로 나눈 $\chi^{2} / d f$ 값은 2.055로 3보다 작아서 적합도 기준에 부합되며, 본 연구에서 CFI 는 .95로 적합도 기준에 부합되었고, 본 연구에서 NFI는 .91로 나타났으 
Table 2. Descriptive Statistics of Observed Variables

$(\mathrm{N}=208)$

\begin{tabular}{|c|c|c|c|c|c|}
\hline Variables & $M \pm S D$ & Min & Max & Skewness & Kurtosis \\
\hline Characteristics of the children (1 5) & $3.13 \pm 0.69$ & 1.00 & 4.48 & -0.61 & -0.10 \\
\hline Parent-Child dysfunctional interaction & $3.00 \pm 0.80$ & 1.00 & 4.64 & -0.54 & -0.33 \\
\hline Difficult child & $3.29 \pm 0.67$ & 1.00 & 4.40 & -0.62 & 0.05 \\
\hline Social support (1 5) & $3.52 \pm 0.60$ & 1.55 & 5.00 & -0.11 & 0.54 \\
\hline Emotional support & $3.54 \pm 0.65$ & 1.71 & 5.00 & -0.14 & -0.11 \\
\hline Informational support & $3.53 \pm 0.63$ & 1.33 & 5.00 & -0.32 & 0.58 \\
\hline Appraisal support & $3.52 \pm 0.59$ & 1.67 & 5.00 & 0.06 & 0.44 \\
\hline Instrumental support & $3.51 \pm 0.68$ & 1.33 & 5.00 & -0.10 & 0.21 \\
\hline \multicolumn{6}{|l|}{ Parenting stress (1 5) } \\
\hline Parental distress & $3.10 \pm 0.78$ & 1.00 & 4.50 & -0.62 & -0.23 \\
\hline Parenting sense of competence (1 5) & $3.40 \pm 0.47$ & 1.70 & 4.97 & -0.19 & 0.60 \\
\hline Healthy parenting ability & $3.71 \pm 0.53$ & 1.75 & 5.00 & -0.34 & 0.49 \\
\hline Learning guidance ability & $3.31 \pm 0.59$ & 1.67 & 5.00 & 0.09 & -0.04 \\
\hline Communication ability & $3.44 \pm 0.57$ & 1.57 & 5.00 & -0.33 & 0.39 \\
\hline Moral training ability & $3.50 \pm 0.61$ & 1.67 & 5.00 & -0.33 & -0.07 \\
\hline General parenting self-efficacy & $3.22 \pm 0.51$ & 1.56 & 4.89 & -0.02 & 0.88 \\
\hline Coping (1 4) & $2.54 \pm 0.38$ & 1.33 & 3.27 & -0.41 & -0.29 \\
\hline Problem-focused coping & $2.58 \pm 0.43$ & 1.10 & 3.60 & -0.36 & 0.09 \\
\hline Emotion-focused coping & $2.49 \pm 0.51$ & 1.00 & 3.67 & -0.07 & 1.34 \\
\hline Quality of life (1 5) & $3.06 \pm 0.47$ & 1.89 & 4.97 & 0.52 & 1.77 \\
\hline Emotional state & $2.88 \pm 0.61$ & 1.25 & 5.00 & 0.13 & 1.00 \\
\hline Physical state and function & $3.07 \pm 0.64$ & 1.25 & 5.00 & 0.24 & -0.07 \\
\hline Self-esteem & $3.19 \pm 0.57$ & 1.63 & 5.00 & 0.34 & 0.71 \\
\hline Relationships with neighbours & $3.17 \pm 0.53$ & 2.00 & 5.00 & 0.49 & 0.94 \\
\hline Family relationships & $3.24 \pm 0.58$ & 1.33 & 5.00 & 0.15 & 0.54 \\
\hline Economic life & $2.99 \pm 0.55$ & 1.60 & 5.00 & 0.31 & 0.84 \\
\hline
\end{tabular}

며 이는 기초모형에 비해 가설적 제안모형이 $91.3 \%$ 향상되었음을 의미 하며 수용가능한 것으로 판정되었다. TLI는 94 로 적합한 것으로 나타 났으며, GFI는 .88이며, GFI값을 자유도를 이용하여 조정한 값인 AGFI 는 84 로 부적합한 것으로 나타났다. 이상에서 살펴본 가설적 모형의 적합도 평가에서 $\chi^{2} / d f(2.055)$ 과 RMR (.02), RMSEA (.07), CFI (.95), NFI (.91), TLI (.94)은 적합한 것으로 나타났으며, GFI (.88), AGFI (.84)는 부적 합한 것으로 나타났다.

\section{가설적 모형의 수정}

본 연구에서는 가설적 모형의 적합도를 높이기 위해 수정지수 (Modification Index, MI)를 이용해 오차들끼리 상관을 갖도록 자유모 수를 추가하는 방법을 사용하였다. 양육효능감의 하위항목인 전반적 인 양육효능감과 학습지도 능력의 오차항(M.I.=11.58), 삶의 질의 하위 항목인 정서상태와 경제환경의 오차항(M.I.=10.86), 자녀 특성의 하위 항목인 자녀의 까다로운 기질과 양육효능감의 하위항목인 건강하게 양육하는 능력 오차항(M.I.=8.96)의 상관을 추가하였다. 수정 모형의 적합도를 평가한 결과 $\chi^{2}$ 는 254.98 ( $\left.p<.001\right)$ 로 부적합하게 나타났으나,
표본의 개수와 비례하여 표본의 크기가 커지면 $\chi^{2}$ 값은 커지므로 비록 유의확률 .05 이하로 나타나더라도 반드시 적합도가 낮다고 할 수 없 다. $\chi^{2} / d f(1.848), \operatorname{RMR}(.02)$, AGFI (.85), RMSEA (.06), CFI (.96), NFI (.92), $\mathrm{TLI}(.95)$ 은 적합한 것으로 나타났으며 GFI (.89)로 모형이 자료에 잘 부 합하는 것으로 나타났다.

\section{수정모형 분석}

수정모형의 경로에 대한 유의성을 검증하기 위하여 자유모수에 대 해 모수치(Parameter Estimates), 임계치(Critical Ratio, C.R.) p값을 확인 하였으며, 다중상관자승(Squared Multiple Correlation, SMC)을 통해 외 생변수인 독립변수들이 내생변수를 어느 정도 설명하는가를 파악하 였다. $\mathrm{ADHD}$ 아동 어머니의 삶의 질과 관련된 수정모형에서 경로는 총 12 개 중 6 개의 경로로 자녀특성에서 양육 스트레스간의 경로 $(p<.001)$, 사회적 지지에서 양육효능감간의 경로 $(p<.001)$, 양육효능감 에서 대처간의 경로 $(p<.001)$, 양육 스트레스에서 삶의 질간의 경로 $(p<.001)$, 양육효능감에서 삶의 질간의 경로 $(p<.05)$, 대처에서 삶의 질 간의 경로 $(p<.01)$ 이다(Table 3$)$. 
Table 3. Confirmatory Factor Analysis, Construct Reliability and Average Variance Extracted of Observed Variables

$(\mathrm{N}=208)$

\begin{tabular}{|c|c|c|c|c|c|c|c|}
\hline \multirow{2}{*}{$\begin{array}{l}\text { Endogenous } \\
\text { variables }\end{array}$} & \multirow{2}{*}{$\begin{array}{c}\text { Exogenous } \\
\text { variables }\end{array}$} & \multicolumn{2}{|c|}{$\begin{array}{l}\text { Hypothetical } \\
\text { model }\end{array}$} & \multicolumn{2}{|c|}{$\begin{array}{l}\text { Modified } \\
\text { model }\end{array}$} & \multirow{2}{*}{$\begin{array}{l}\text { Construct } \\
\text { reliability }\end{array}$} & \multirow{2}{*}{$\begin{array}{l}\text { Average } \\
\text { variance } \\
\text { extractec }\end{array}$} \\
\hline & & SFL & $p$ & SFL & $p$ & & \\
\hline \multirow{2}{*}{$\begin{array}{l}\text { Children } \\
\text { characteristics }\end{array}$} & Parent-Child dysfunctional interaction & 0.90 & $<.001$ & 0.96 & $<.001$ & \multirow[t]{2}{*}{.92} & \multirow[t]{2}{*}{.85} \\
\hline & Difficult child & 0.90 & $<.001$ & 0.96 & $<.001$ & & \\
\hline Parenting stress & Parenting stress & - & - & - & - & - & - \\
\hline \multirow[t]{4}{*}{ Social support } & Emotional support & 0.93 & $<.001$ & 0.93 & $<.001$ & \multirow[t]{4}{*}{.99} & \multirow[t]{4}{*}{.94} \\
\hline & Informational support & 0.94 & $<.001$ & 0.94 & $<.001$ & & \\
\hline & Appraisal support & 0.91 & $<.001$ & 0.92 & $<.001$ & & \\
\hline & Instrumental support & 0.90 & $<.001$ & 0.91 & $<.001$ & & \\
\hline \multirow{5}{*}{$\begin{array}{l}\text { Sense of competence } \\
\text { in Parenting }\end{array}$} & Healthy parenting ability & 0.88 & $<.001$ & 0.84 & $<.001$ & \multirow[t]{5}{*}{.98} & \multirow[t]{5}{*}{.92} \\
\hline & Learning guidance ability & 0.86 & $<.001$ & 0.88 & $<.001$ & & \\
\hline & Communication ability & 0.92 & $<.001$ & 0.91 & $<.001$ & & \\
\hline & Moral training ability & 0.72 & $<.001$ & 0.74 & $<.001$ & & \\
\hline & General parenting self-efficacy & 0.91 & $<.001$ & 0.92 & $<.001$ & & \\
\hline \multirow[t]{2}{*}{ Coping } & Problem-focused coping & 1.15 & $<.001$ & \multirow[t]{2}{*}{-} & \multirow[t]{2}{*}{-} & & \\
\hline & Emotion-focused coping & 0.31 & .034 & & & & \\
\hline \multirow[t]{6}{*}{ Quality of life } & Emotional state & 0.54 & $<.001$ & 0.50 & $<.001$ & \multirow[t]{6}{*}{.97} & \multirow[t]{6}{*}{.85} \\
\hline & Physical state and function & 0.78 & $<.001$ & 0.75 & $<.001$ & & \\
\hline & Self-esteem & 0.92 & $<.001$ & 0.93 & $<.001$ & & \\
\hline & Relationships with neighbours & 0.77 & $<.001$ & 0.77 & $<.001$ & & \\
\hline & Family relationship & 0.81 & $<.001$ & 0.82 & $<.001$ & & \\
\hline & Economic life & 0.82 & $<.001$ & 0.83 & $<.001$ & & \\
\hline
\end{tabular}

SFL=Standardized factor loading.

수정모형의 모수치 추정결과에서 제시된 변수들간의 효과를 직 . 간접 효과 및 총효과를 유의수준 .05 에서 통계적 유의성을 검정한 결 과는 Table 4에 제시하였다. 양육 스트레스에 직접적으로 영향을 미치 는 변수는 자녀특성 $(\gamma=.81$, C.R. $=12.65)$ 으로 $71.8 \%$ 의 설명력을 나타내 고, 양육효능감에 직접적으로 영향을 미치는 변수는 사회적 지지 $(\gamma$ $=.78$, C.R. $=10.59$ )로 설명력은 $55.3 \%$ 이며, 대처에 직접적으로 영향을 미치는 변수는 양육효능감 $(\beta=.52$, C.R. $=5.05)$ 으로 설명력은 $27.9 \%$ 로 나타났으며 양육 스트레스와 양육효능감간의 상관관계 $(\beta=.05$, C.R. $=0.59)$ 는 통계적으로 유의한 영향을 미치지 않았다. 삶의 질에 직 접적인 영향을 미치는 변수는 양육 스트레스 $(\beta=-.41, C . R .=-4.81)$, 양 육효능감 $(\beta=.23$, C.R. $=2.28)$, 대처( $\beta=.22$, C.R. $=3.15)$ 로 이들 변수는 의 해 $\mathrm{ADHD}$ 아동 어머니의 삶의 질을 $52.1 \%$ 설명하는 것으로 나타났다 (Table 4)(Figure 2).

\section{가설 검정}

\section{양육 스트레스를 내생변수로 하는 가설}

가설 1. '자녀의 특성은 양육 스트레스에 양 $(+)$ 의 영향을 미칠 것이다 $\left(\gamma_{11}\right)$ 는 직접효과 $(\gamma=.81, p<.001)$ 가 유의하게 나타나 가설이 지지되었다.

가설 2. 사회적 지지는 양육 스트레스에 음(-)의 영향을 미칠 것이다( $\gamma$ $\left.{ }_{12}\right)^{\prime}$ 는 직접효과 $(\gamma=-.07, p=.146)$ 는 유의하지 않아 가설이 기각되었다.

\section{양육효능감을 내생변수로 하는 가설}

가설 3. '자녀의 특성은 양육효능감에 음(-)의 영향을 미칠 것이다( $\gamma$ $21)$ 는 직접효과 $(\gamma=.08, p=.217)$ 는 유의하지 않아 가설이 기각되었다.

가설 4. 사회적 지지는 양육효능감에 양(+)의 영향을 미칠 것이다( $\gamma$ $22)^{\prime}$ 는 직접효과 $(\gamma=.78, p<.001)$ 가 유의하게 나타나 가설이 지지되었다.

가설 5. 양육 스트레스와 양육효능감은 서로 영향을 미칠 것이다( $\beta$ $\left.{ }_{21}, \beta_{12}\right)^{\prime}$ 는 서로 유의한 영향 $(\beta=.05, p=.577)$ 을 미치지 않아 가설이 기각 되었다.

\section{대처를 내생변수로 하는 가설}

가설 6. 사회적 지지는 대처에 양 $(+)$ 의 영향을 미칠 것이다 $\left(\gamma_{32}\right)$ '는 직 접효과 $(\gamma=.03, p=.807)$ 는 유의하지 않았지만 간접효과 $(\gamma=.40, p<.001)$ 및 총효과 $(\gamma=.43, p<.001)$ 가 유의하게 나타나 지지되었다.

가설 7. '양육 스트레스는 대처에 음(-)의 영향을 미칠 것이다( $\left(\beta_{31}\right)$ 는 직접효과 $(\beta=.05, p=.466)$ 는 유의하지 않아 가설이 기각되었다.

가설 8. '양육효능감은 대처에 양 $(+)$ 의 영향을 미칠 것이다 $\left(\beta_{32}\right)$ '는 직 접효과 $(\beta=.52, p<.001)$ 가 유의하게 나타나 지지되었다. 
Table 4. Standardized Estimates, CR, SMC, Standardized Direct, Indirect, and Total Effects for the Hypothetical Model

$(\mathrm{N}=208)$

\begin{tabular}{|c|c|c|c|c|c|c|c|c|c|c|}
\hline \multirow{2}{*}{$\begin{array}{l}\text { Endogenous } \\
\text { variables }\end{array}$} & \multirow{2}{*}{$\begin{array}{c}\text { Exogenous } \\
\text { variables }\end{array}$} & \multirow[t]{2}{*}{ SE } & \multirow[t]{2}{*}{$\mathrm{CR}(p)$} & \multirow[t]{2}{*}{ SMC } & \multicolumn{2}{|c|}{$\begin{array}{l}\text { Direct } \\
\text { effect }\end{array}$} & \multicolumn{2}{|c|}{ Indirect effect } & \multicolumn{2}{|c|}{$\begin{array}{l}\text { Total } \\
\text { effect }\end{array}$} \\
\hline & & & & & SE & $p$ & SE & $p$ & SE & $p$ \\
\hline \multirow[t]{2}{*}{ Parenting stress } & Children characteristics & .81 & $12.65(<.001)$ & .718 & .81 & $<.001$ & - & & .81 & $<.001$ \\
\hline & Social support & -.07 & $-1.46(.146)$ & & -.07 & .146 & - & & -.07 & .146 \\
\hline \multirow{2}{*}{$\begin{array}{l}\text { Sense of competence } \\
\text { in parenting }\end{array}$} & Children characteristics & .08 & $1.24(.217)$ & .553 & .08 & .217 & - & & .08 & .217 \\
\hline & Social support & .78 & $10.59(<.001)$ & & .78 & $<.001$ & - & & .78 & $<.001$ \\
\hline \multirow[t]{4}{*}{ Coping } & Children characteristics & & & & - & & .08 & .272 & .08 & .272 \\
\hline & Social support & .03 & $0.25(.807)$ & .279 & .03 & .807 & .40 & $<.001$ & .43 & $<.001$ \\
\hline & Parenting stress & .05 & $0.73(.466)$ & & .05 & .466 & - & & .05 & .466 \\
\hline & Parenting sense of competence & .52 & $5.05(<.001)$ & & .52 & $<.001$ & - & & .52 & $<.001$ \\
\hline \multirow[t]{5}{*}{ Quality of life } & Children characteristics & & & .521 & - & & -.29 & .001 & -.29 & .001 \\
\hline & Social support & .13 & $1.35(.178)$ & & .13 & .178 & .31 & $<.001$ & .43 & $<.001$ \\
\hline & Parenting stress & -.41 & $-4.81(<.001)$ & & -.41 & $<.001$ & .01 & .510 & -.40 & $<.001$ \\
\hline & Parenting sense of competence & .23 & $2.28(.023)$ & & .23 & .023 & .12 & .002 & .35 & $<.001$ \\
\hline & Coping & .22 & $3.15(.002)$ & & .22 & .002 & . & & .22 & .002 \\
\hline \multicolumn{2}{|c|}{ Parenting stress $\leftrightarrow$ Parenting sense of competence } & .05 & $0.59(.577)$ & & & & & & & \\
\hline
\end{tabular}

$\mathrm{SE}=$ Standardized estimates; $\mathrm{SMC}=$ Squared multiple correlation; $\mathrm{CR}=$ Critical ratio.

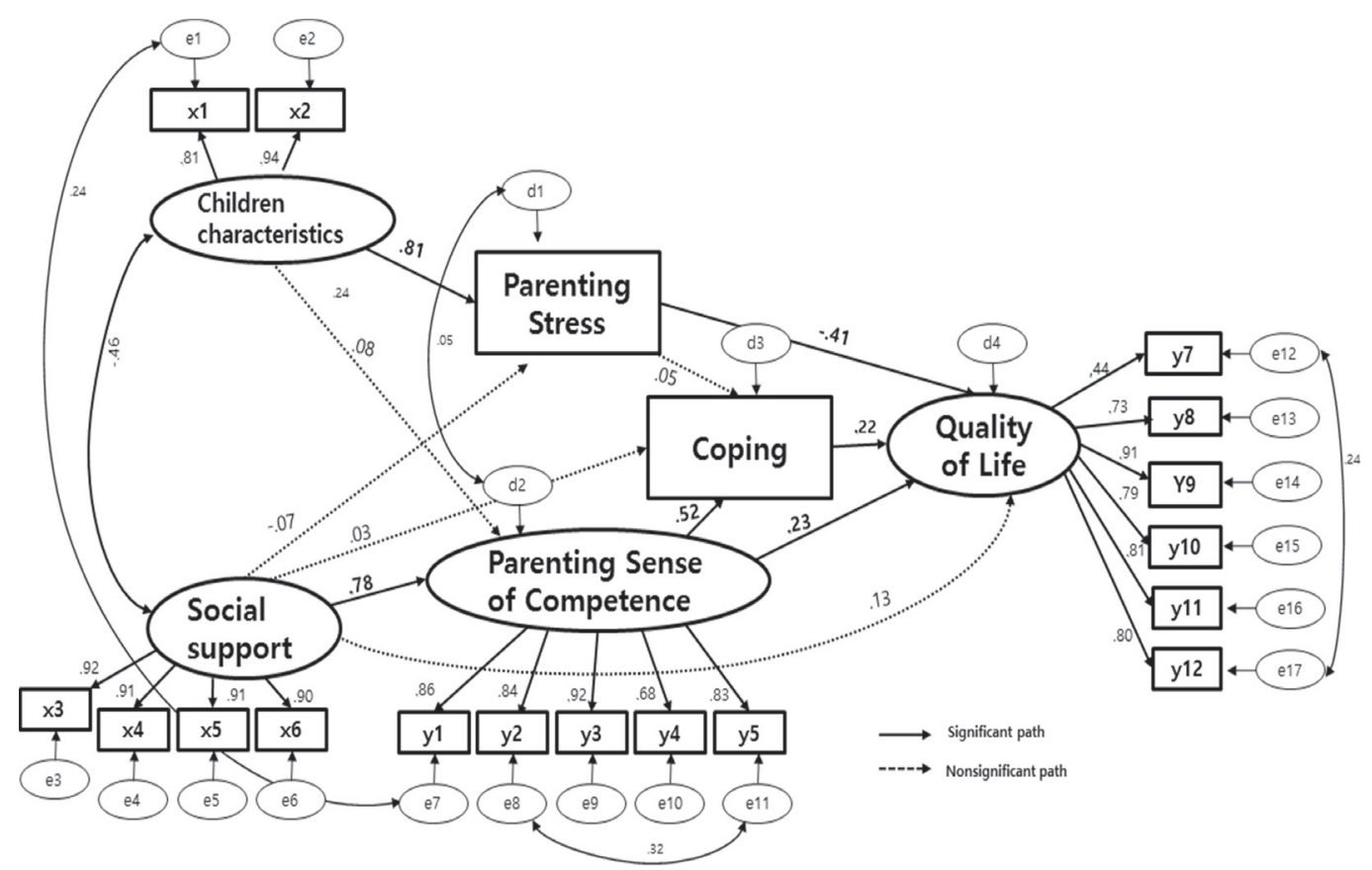

x1: Difficult child
x2: Parent-Child Dysfunctional interaction
x3: Emotional support
x4: Infomational support
x5: Appraisal support
x6: Instrumental support

x1:Difficult child $X 2$ : Parent-Child Dysfunctional interaction x3: Emotional support $\mathrm{x} 4$ : Infomational support x6: Instrumental support
y1:Parental distress y2: Healthy parenting ability y3: Learning guidance ability y4: Communication ability y5: Moral training ability y6: General parenting self-efficacy y7: Emotional state y8: Physical state and function y9: Self-esteem y10: Relationships with neighbours y11:Family relationship y12: Economic life

Figure 2. Path diagram of modified model. 


\section{삶의 질을 내생변수로 하는 가설}

가설 9. 사회적 지지는 삶의 질에 양 $(+)$ 의 영향을 미칠 것이다 $\left(\gamma_{42}\right)^{\prime}$ 는 직접효과 $(\gamma=.13, p=.178)$ 는 유의하지 않았지만 간접효과 $(\gamma=.31$, $p<.001)$ 및 총효과 $(\gamma=.43, p<.001)$ 가 유의하게 나타나지지되었다.

가설 10 . '양육 스트레스는 삶의 질에 음(-)의 영향을 미칠 것이다( $\beta$ $\left.{ }_{41}\right)^{\prime}$ 는 직접효과 $(\beta=-.41, p<.001)$ 가 유의하게 나타나고, 간접효과 $(\beta=.01$, $p=.510)$ 는 유의하지 않았으나 총효과 $(\beta=-.39, p<.001)$ 가 유의하게 나 타나가설이 지지되었다.

가설 11. '양육효능감은 삶의 질에 양 $(+)$ 의 영향을 미칠 것이다 $\left(\beta_{42}\right)$ ' 는 직접효과 $(\beta=.23, p<.05)$ 가 유의하게 나타났으며, 간접효과 $(\beta=.12$, $p<.05)$ 및 총효과 $(\beta=.35, p<.001)$ 도 유의하게 나타나 지지되었다.

가설 12 . '대처는 삶의 질에 양 $(+)$ 의 영향을 미칠 것이다 $\left(\beta_{43}\right)$ '는 직접 효과 $(\beta=.22, p<.05)$ 가 유의하게 나타나 지지되었다.

\section{논 의}

본 연구는 $\mathrm{ADHD}$ 아동 어머니의 삶의 질을 설명하는 구조모형을 구축하기 위해 Lazarus와 Folkman[12]의 스트레스-평가-대처 이론과 Cohen과 Wills[13]의 사회적 지지를 매개변수로 가설적 모형을 구축하 였다. 본 연구에서는 선행 연구에서 제시된 삶의 질 관련 요인들 중에 서 스트레스 요인은 자녀의 특성, 인지적 평가요인은 양육 스트레스와 양육효능감으로 설정하였으며 Cohen과 Wills[13]의 사회적 지지를 매 개변수로 삶의 질에 미치는 영향을 파악하고, 삶의 질에 영향을 주는 요인들의 직. 간접 효과를 규명하여 $\mathrm{ADHD}$ 아동 어머니의 삶의 질 증 진을 위한 효과적인 간호전략을 개발하는데 기초자료를 제공하고자 시도하였다.

본 연구에서 구축된 $\mathrm{ADHD}$ 아동 어머니의 삶의 질에 대한 가설적 모형은 외생변수에 자녀 특성, 사회적 지지를 설정하였고, 내생변수 에 양육 스트레스, 양육효능감, 대처 및 삶의 질을 설정하여 모형의 적 합도와 직 - 간접 경로의 유의성을 검증하였다. 가설적 모형에 대해 $\chi^{2}$, $\chi^{2} / d f$, RMR, GFI, AGFI, RMSEA, CFI, NFI, TLI 지수를 이용하여 모형의 적합도를 평가하였다. 먼저 측정변수에 대한 확인적 요인분석을 통해 요인적재치가 0.5 이하인 정서중심적 대처를 제거하고 모형을 구축하 였다. 가설적 모형의 적합도를 검증한 결과 $\chi^{2}, \mathrm{GFI}, \mathrm{AGFI}$ 가 적합하지 않아 적합도를 높이기 위하여 수정지수(MI)를 통해 오차항간의 상관 을 추가하였다. 전반적인 양육효능감과 학습지도 능력, 정서상태와 경 제환경, 자녀의 까다로운 기질과 건강하게 양육하는 능력의 오차항 의 상관을 추가하여 수정모형을 제시하였다. 수정모형의 적합도 분석 결과, $\chi^{2}$ 값을 제외한 $\chi^{2} / d f, \mathrm{RMR}, \mathrm{AGFI}, \mathrm{RMSEA}, \mathrm{CFI}, \mathrm{NFI}, \mathrm{TLI}$ 는 적합 한 것으로 나타났으며 GFI는 다소 적합도 지수가 낮은 것으로 나타났 으나 AGFI가 GFI보다 낮게 나오며, 85 이상이면 그 모형의 적합도는
좋은 것으로 간주할 수 있어, 본 연구의 최종모형으로 확정하였다. $\mathrm{ADHD}$ 아동 어머니의 삶의 질 구조모형에 관한 선행 연구가 없어서 모형을 직접 비교하는 것은 불가능하였지만, 본 연구의 $\mathrm{ADHD}$ 아동 어머니의 삶의 질 수정모형에서 양육 스트레스, 양육효능감, 사회적 지지, 대처가 삶의 질을 $52.3 \%$ 설명한다는 결과는 모형에 설정된 각 요 인들이 삶의 질을 통합적으로 잘 설명한다고 판단된다. 그러나 대처 에 대한 설명력은 $27.9 \%$ 로 낮아 추후 $\mathrm{ADHD}$ 아동 어머니의 $\mathrm{ADHD}$ 아 동 양육관련 대처에 영향을 미치는 주요 영향요인을 규명하는 연구 가 필요하다.

본 연구 대상자의 삶의 질은 5점 만점에 3.06점이며, 이는 동일한 측 정도구로 종합병원에 입원 중인 만성질환아동 어머니의 삶의 질을 2.70 2.91점으로 보고한 연구[22]의 결과보다는 높았으나, 간질아동 어 머니의 삶의 질을 3.68점으로 보고한 연구[23]의 결과보다는 낮았다. 이와 같은 결과는 현재 질환을 진단받았으나 지역사회에 거주하는 아 동 어머니의 삶의 질이 입원한 아동 어머니의 삶의 질보다는 높다는 것을 의미한다.

본 연구에서 제시한 수정모형에 의하면 $\mathrm{ADHD}$ 아동 어머니의 삶의 질에 영향을 미치는 요인은 양육 스트레스, 양육효능감, 대처 순으로 나타났다. 사회적 지지는 양육효능감과 대처를 통해 삶의 질에 영향을 미쳤고, 자녀특성은 양육 스트레스를 통해 삶의 질에 영향을 미치는 요인으로 나타났으며 삶의 질에 설명력이 가장 큰 요인은 사회적 지지 이었다. 사회적 지지는 $\mathrm{ADHD}$ 아동 어머니의 삶의 질에 직접적으로 영 향을 미치지 않지만, 양육효능감, 대처를 매개로 간접효과와 총효과 모 두 유의한 영향을 미쳤다.

본 연구에서 사회적 지지는 5점 만점에 3.52점으로, 동일한 도구를 사용한 선행 연구 결과와 비교해 보면, $\mathrm{ADHD}$ 아동 어머니를 대상으 로 한 연구[15]의 결과와 유사하였다. $\mathrm{ADHD}$ 아동 어머니를 대상으로 한 선행 연구가 없어 직접 비교는 어려우나 발달장애 아동어머니의 지 각된 사회적 지지가 높을수록 심리적 안녕감이 높다는 선행연구[24] 결과를 근거로 질환을 않고 있는 아동이나 장애아동 어머니의 삶의 질을 높이기 위해 사회적 지지를 높이는 전략이 필요하다고 판단된다.

두 번째로 삶의 질에 영향이 큰 변수는 양육 스트레스이었다. 본 연 구에서 양육 스트레스는 5점 만점에 3.10점으로, 동일한 측정도구를 사용한 연구 결과와 비교하면, 일반아동 어머니의 양육 스트레스를 5 점 만점에 2.24점으로 보고한 연구[25] 결과보다 높았다. 이는 일반아 동 어머니의 양육 스트레스는 2.00 점, $\mathrm{ADHD}$ 아동 어머니의 양육 스트 레스는 2.61점으로 보고한 선행 연구[26] 결과와 유사하다. 아와 같은 결과는 $\mathrm{ADHD}$ 아동 어머니들은 일반 아동 어머니에 비해 높은 양육 스트레스를 경험하며, 삶이 질이 낮다는 선행 연구[8,10] 결과로 설명 할 수 있다. 이와 같은 결과를 근거로 $\mathrm{ADHD}$ 아동 어머니의 양육 스트 레스를 감소시킴으로써 삶의 질을 높일 수 있는 전략을 개발하는 것 
이 필요하다.

본 연구에서 양육효능감은 삶의 질에 직접효과 $(\beta=.23)$ 와 간접효과 $(\beta=.12)$ 가 있었으며, 5 점 만점에 3.40점이었다. 일반아동의 어머니의 양 육효능감은 3.77점[14]으로 본 연구 결과보다 높았다. 이는 $\mathrm{ADHD}$ 아동 어머니는 일반 아동 어머니에 비해 양육효능감이 낮은 것을 의미한다.

본 연구에서 대처의 하위영역인 문제중심적 대처는 4 점 만점에 2.58 점, 정서중심적 대처는 2.49점이었다. 이는 선행 연구[26]에서 $\mathrm{ADHD}$ 아동의 어머니와 아버지 모두 정서중심적 대처보다 문제중심적 대처 를 하는 것으로 보고한 결과와 유사하였으며, 이는 ADHD 아동 어머 니들은 스트레스 상황을 극복하기 위하여 소극적인 대처방식을 사용 한다는 것을 의미한다. $\mathrm{ADHD}$ 아동 어머니의 양육효능감과 대처와의 관계에 대한 선행 연구 결과가 없어 직접적으로 비교하기는 어려웠지 만, 양육효능감이 대처에 영향을 주고 대처는 삶의 질에 영향을 주는 본 연구의 결과는 $\mathrm{ADHD}$ 아동 어머니의 삶의 질을 높이기 위해서는 $\mathrm{ADHD}$ 아동 어머니가 $\mathrm{ADHD}$ 아동 양육과 관련된 문제에 대해 문제 중심적 대처를 할 수 있도록 문제해결 능력을 증진시키는 중재가 필요 하다는 것을 시사한다.

본 연구에서는 자녀의 특성과 사회적 지지는 양육 스트레스를 $71.8 \%$ 설명하지만 자녀의 특성만 양육 스트레스에 직접적으로 영향을 미치고, 사회적 지지는 직접 영향을 미치지 않는 것으로 나타났다. 이 는 $\mathrm{ADHD}$ 아동 어머니는 아동의 기질적인 행동에 의한 어려움보다는 사회적 편견이나 사회적 지원의 부족으로 병원, 학교, 사회에서 소외된 자로 살아가는 경험을 하게 되고, 정상 아동도, 장애 아동도 아닌 경계 에 있는 애매모호함으로 스트레스를 많이 받고 있어 양육부담도 높았 다고 보고한 선행 연구[10]의 결과와 차이가 있다. 이와같은 차이는 본 연구에서는 사회적 지지를 가족지지로 측정하였기 때문으로 생각한 다. $\mathrm{ADHD}$ 아동 어머니는 아동이 학교 생활하는데서 발생하는 어려 움, 의사나 전문기관을 이용하는 것의 어려움, 질병에 대한 사회적 인 식부족, $\mathrm{ADHD}$ 에 대한 정보부족, 경제적 어려움을 겪고 있으므로[10] 추후에는 모형에 가족의 지지와 함께 학교, 지역사회, 국가의 제도 등 과같은 사회적 지지를 추가하는 것이 필요하다.

본 연구의 최종모형에서 자녀의 특성은 양육효능감에 영향을 미치 지 않으며, 양육 스트레스와 양육효능감간의 상관관계도 유의하지 않 았다. 이는 향후 양육 스트레스와 양육효능감을 설명할 수 있는 매개 변수에 대한 연구가 필요함을 시사한다.

본 연구에서 사회적 지지가 삶의 질에 양육 스트레스, 양육효능감 및 대처를 통해 간접적으로 영향을 미치는 것으로 나타났다. 이와 같 은 결과는 Lee[15]가 ADHD 아동 어머니의 양육 스트레스에 대한 내적 인 대처자원은 양육효능감으로, 외적인 대처자원은 사회적 지지로 설 정하여 양육 스트레스, 대처자원, 양육행동간의 관계를 분석하여 양 육효능감과 사회적 지지가 양육행동에 중요한 매개변수임을 보고한
연구 결과와도 일치한다. 이는 양육효능감이 높은 부모는 개인적 자원 과 사회적 지원을 적절하게 활용하는 것으로 보고한 선행 연구[28] 결 과로 설명할 수 있다.

결론적으로 본 연구에서 구축된 $\mathrm{ADHD}$ 아동 어머니의 삶의 질 구 조모형을 근거로 $\mathrm{ADHD}$ 아동 어머니를 위한 양육역량증진 프로그램 을 개발하여 적용하고, 가정-학교-병원-지역사회가 $\mathrm{ADHD}$ 아동과 어 머니를 체계적으로 지원하는 사회적 지지 시스템을 갖춘다면 $\mathrm{ADHD}$ 아동 어머니의 삶의 질은 증진될 것이다.

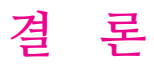

본 연구는 Lazarus와 Folkman[11]의 스트레스-평가-대처이론을 토대 로 $\mathrm{ADHD}$ 아동 어머니의 삶의 질에 영향을 미치는 요인을 규명하고 삶의 질 구조모형을 구축한 후 이를 검증함으로서 $\mathrm{ADHD}$ 아동 어머 니의 삶의 질을 증진시킬 수 있는 간호중재를 개발하는데 기초자료를 제공하고자 시도되었다. 2014년 10월 1일부터 2015년 4월 10일까지 경 남, 서울, 부산 지역의 $\mathrm{ADHD}$ 아동 보호자 모임, 정신치료기관과 지역 사회 정신보건센터 및 사회재활시설과 $\mathrm{G}$ 대학교병원에서 자료를 수집 하였으며 208명의 자료를 최종 분석하였다. 자료 분석은 SPSS 18.0과 $\mathrm{AMOS} 18.0$ program을 이용하여 가설적 모형의 적합도를 검증하고 $\mathrm{ADHD}$ 아동 어머니의 삶의 질에 영향을 미치는 요인들의 직 · 간접 효 과를 파악하였다. 본 연구의 가설적 모형에서 외생변수는 $\mathrm{ADHD}$ 아 동의 특성과 $\mathrm{ADHD}$ 아동 어머니가 지각한 사회적 지지이며 양육 스트 레스, 양육효능감, 대처 및 삶의 질을 내생변수로 설정하고 직. 간접 경 로의 유의성을 검증하였다.

수정모형의 적합도를 검증한 결과 절대적합지수 중 $\chi^{2}$ 값을 제외한 $\chi$ ${ }^{2} / d f$, RMR, RMSEA, GFI, AGFI, 증분적합지수 NFI, CFI, TLI 지수가 적 합한 것으로 나타나 본 연구의 최종 모형으로 확정하였다. 수정 모형에 서 12 개의 경로 중 6 개의 경로가 지지되었고 삶의 질에 유의하게 나타 난 경로는 자녀특성에서 양육 스트레스간의 경로, 사회적 지지와 양육 효능감의 경로, 양육효능감과 대처의 경로, 양육 스트레스와 삶의 질 의 경로, 양육효능감과 삶의 질의 경로, 대처와 삶의 질의 경로이었다 $\mathrm{ADHD}$ 아동 어머니의 삶의 질에 자녀특성, 사회적 지지는 간접효과를 양육 스트레스, 양육효능감과 대처는 직접효과가 유의한 것으로 나타 나이들 변수가 삶의 질을 $52.3 \%$ 설명하였다.

본 연구를 통해 구축된 $\mathrm{ADHD}$ 아동 어머니의 삶의 질 구조모형은 $\mathrm{ADHD}$ 아동 어머니의 삶의 질에 대한 설명력이 높아 $\mathrm{ADHD}$ 아동 어 머니의 삶의 질을 설명하는 모형으로 제안하며 이 모형을 $\mathrm{ADHD}$ 아 동 어머니의 삶의 질 증진을 위한 간호중재 프로그램을 개발할 때 기 초자료로 활용할 것을 제안한다. 


\section{Conflict of Interest}

No potential conflict of interest relevant to this article was reported.

\section{References}

1. American Psychiatric Association. Diagnostic and statistical manual of mental disorders: DSM-5. 5th ed. Gwon JS, translator. Seoul: Hakjisa; 2015. p. 61-62.

2. Seoul Youth Regional Mental Health Center. Prevalence of mental disorders in children and adolescents in Seoul. Epidemiological Survey Report. Seoul: Seoul Youth Regional Mental Health Center; 2005.

3. Health Insurance Review \& Assessment Service. 8 in 10 ADHD children and adolescents are men [Internet]. Seoul: Health Insurance Review \& Assessment Service; 2012 [cited 2012 May 10]. Available from:

https://www.hira.or.kr/dummy.do?pgmid=HIRAA020041000000\&c msurl=/cms/inform/02/1211821_27116.html\&subject=\%EC\%86\%8C \%ЕC\%95\%84\%C2\%B7\%EC\%B2\%AD\%EC\%86\%8C\%EB\%85\%84\%20 \%ЕC\%A3\%BC\%EC\%9D\%98\%EB\%A0\%A5\%ЕA\%B2\%B0\%ED\%95\%8 D\%EC\%9E\%A5\%ЕC\%95\%A0,\%2010\%ЕB\%AA\%85\%ЕC\%A4\%91\%20 8\%ЕB\%AA\%85\%20\%27\%27\%E7\%94\%B7\%27\%27

4. Sin HG, Kim JS. Attention deficit hyperactivity disorder. 1st ed. Seoul: Hakjisa; 2016. p 18-23.

5. Lee SH, Yoon HY. The effects of family play therapy on family functions with ADHD tendentious child and the ADHD tendencies of children. Journal of Emotional \& Behavioral Disabilities. 2007;23 (3):25-50.

6. Oh WO. Factors influencing family quality of life among mothers of children with ADHD. Journal of Korean Academy of Child Health Nursing. 2008;14(4):394-404.

7. Seo MJ, Chang EJ, Jung CH, Chei SY. The study of the parenting stress, depression and parenting efficacy on the mother of attention deficit hyperactivity disorder children. The Korean Journal of Woman Psychology. 2003;8(1):69-81.

8. Kim HS. Rearing experience of mothers having children with ADHD based grounded theory. Journal of Family and Culture. 2007;19 (4):193-222.

9. Koo CS, Park JH. A study on mothers' coping experience of ADHD children. Korean Journal of Qualitative Research in Social Welfare.
2012;6(1):5-39.

10. Whalen CK, Henker B, Jamner LD, Ishikawa SS, Floro JN, Swindle R, et al. Toward mapping daily challenges of living with ADHD: Maternal and child perspectives using electronic diaries. Journal of Abnormal Child Psychology. 2006;34(1):111-126. https://doi.org/10.1007/s10802-005-9008-5

11. Kendall J, Leo MC, Perrin N, Hatton D. Modeling ADHD child and family relationships. Western Journal of Nursing Research. 2005; 27(4):500-518.

http://journals.sagepub.com/doi/pdf/10.1177/0193945905275513

12. Lazarus RS, Folkman S. Stress, appraisal and coping. 1st ed. New York: Springer Publishing Company; 1984. p. 22-52.

13. Cohen S, Wills TA. Stress, social support, and the buffering hypothesis. Psychological Bulletin. 1985;98(2):310-357. https://doi.org/10.1037//0033-2909.98.2.310

14. Kim MA, Seo JY, Park WJ. Relationship of mothers' recognition of attention deficit hyperactivity disorder (ADHD), parenting stress and family support in children diagnosed with ADHD. Journal of Korean Academy of Child Health Nursing. 2011;17(2):127-135. https://dx.doi.org/10.4094/jkachn.2011.17.2.127

15. Lee JH. The effects of parenting stress on parenting behavior among mothers of children with ADHD: Focusing on the mediating effects of parenting self-efficacy and social support [master's thesis]. Seoul: Seoul National University; 2013.p. 1-106.

16. Abidin RR. Parenting stress index (PSI) manual. 3rd ed. Odessa; Psychological Assessment Resources; 1995. p. 29.

17. Kim HM, Do HS. Maternal parenting stress, efficacy, and behavior: Relations to children's social competence. Korean Journal of Child Health Nursing. 2004;25(6):279-298.

18. Park JW. Study to development a scale of social support [master's thesis]. Seoul: Yonsei University; 1985. p. 1-127.

19. Choi HS, Chung OB. The development of an inventory for measuring the parenting self - efficacy of Korean mothers. Korean Journal of Child Studies. 2001;22(3):1-15.

20. Park JS, Shin HJ, Park AS. Relationships among mother's thinking styles, stress coping styles, and child-rearing stress. Korean Journal of Child Studies. 2008;29(3):55-72.

21. No YJ. Analytical study of the quality of life of the middle-aged in Seoul [dissertation]. Seoul: Yonsei University; 1988. p. 1-86.

22. Choi MA, Lee HS, Kim DH, Park MH, Yoon SY, Cho YH, et al. The study on the quality of life for the mothers of hospitalized chronic 
pediatric patients. Korean Journal of Child Health Nursing. 2000;6 (2):249-261.

23. Kim NE. The factors affecting quality of life among mothers with epileptic child. Mental Health and Social Work. 2011;27:5-34.

24. Lee SJ, O SS. The relationship between the parenting stress and psychological well-being the mothers of the child with the disability: Testing a mediating model of active coping strategy and social support. The Korea Journal of Counseling. 2006;7(1):27-45.

25. Kim EK, Koh CK. The relation of parenting stress, anger and somatization symptom of mothers. The Korean Journal of Stress Research. 2016;24(3):151-160. https://doi.org/10.17547/kjsr.2016.24.3.151

26. Kim SY. Relationship among children's ADHD symptoms, parenting stress and behavior regarding nurturing. The Journal of the Korea Contents Association. 2011;11(11):221-230.

https://doi.org/10.5392/JKCA.2011.11.11.221

27. McKee TE, Harvey E, Danforth JS, Ulaszek WR, Friedman JL. The relation between parental coping styles and parent-child interactions before and after treatment for children with ADHD and oppositional behavior Journal of Clinical Child \& Adolescent Psychology. 2004;33(1):158-168. https://doi.org/10.1207/S15374424JCCP3301_15

28. Teti DM, Gelfand DM. Behavioral competence among mothers of infants in the first year: The mediational role of maternal self-efficacy. Child Development. 1991;62:918-929. https://doi.org/10.2307/1131143 